DOI: $10.2478 /$ aucft-2013-0010

\title{
EFFECT OF THE NEW TECHNOLOGY OF CATTLE HOUSING WATERBEDS ON COMFORT, HEALTH AND MILK PRODUCTION
}

\author{
Anna ŠIMKOVÁ*1, Miloslav ŠOCH*, Kateřina ŠVEJDOVÁ*, LUBOŠ \\ ZÁBRANSKÝ*, Pavel NOVÁK*, Jan BROUČEK**, Bohuslav ČERMÁK*, \\ Václav PÁLKA*, Kristýna ŠIMÁK-LÍBALOVÁ* \\ *University of South Bohemia in České Budějovice, Faculty of Agriculture, \\ Department of Veterinary Sciences and Product Quality, 370 05, Studentská \\ 13, České Budějovice, Czech Republic \\ ** Animal Production Research Centre Nitra, Slovak Republic
}

\begin{abstract}
A new housing technology double-chamber cow waterbeds should provide the animals with greater comfort improve their health and increase milk production. The study was carried out in the stable for dairy cows and heifers. They were stabled in free-stall housing. Rubber mattresses had been replaced with double-chamber cow waterbeds. The aim of the study was to determine their effect on comfort, health, occurrence of mastitis, count of somatic cells, total milk production. The study confirmed the reduction of number of animals with injuries of feet and incidence of mastitis. The values of somatic cells in milk were constant. Positive effect was shown with fluent increase in milk production. It increased the number of cows and heifers lying in the boxes.
\end{abstract}

Keywords: dairy cows, double chamber cow waterbeds, cow comfort, health condition, milk production

\footnotetext{
${ }^{1}$ Anna Šimková. University of South Bohemia in České Budějovice, Faculty of Agriculture, Department of Veterinary Sciences and Product Quality, 370 05, Studentská 13, České Budějovice, Czech Republic. E-mail: anna-simkova@seznam.cz
}

Vol. XVII (2013), no.2 


\section{INTRODUCTION}

The phrase "comfort of dairy cattle" is among milk producers commonly widespread. Research about it, what method of cattle housing is the best and which technology of housing to choose, make the most improved comfort and welfare of dairy cattle and reduce unwanted risks associated with illness or injury of the animals at the same time, it is expanding slowly. The need to ensure of sufficient welfare for animals demonstrates in study (Cziszter et al., 2011). Interviewed farmers reported in $70 \%$ of cases need to improve welfare in dairy cows.

The correct choice of bedding material may for example influence the risk of udder infection (Weary et al., 2003) and to prevent diseases of the limbs (Vokey et al., 2001) such as the hocks and knees injuries (Mowbray et al., 2003).

Choice of type of bedding is relatively wide. It is possible to choose for example straw, wood sawdust, separated slurry and rubber mattress or double-chamber cow waterbeds. In terms of improved health, milk production, comfort and maintenance is very interesting of use of doublechamber cow waterbeds.

Double chamber waterbeds are made up of a system of rubber bladders filled with water. They are made using multiple layers of rubber for durability and two layers of nylon webbing for strength. Patented double-chamber system divides the bed into two cushions. Smaller cushion is intended for knees of cows and larger cushion for the cow's body. The back edge of the bed is skewed at 35degree angle which makes possible a smooth transition from the surface of the waterbed into the space.

Waterbeds are made in size: longitudinal side $182.9 \mathrm{~cm}$, width from $106.7 \mathrm{~cm}$ to $137.2 \mathrm{~cm}$. Waterbeds are cut to reflect the number of standing spaces for a specific platform. Beds are anchored by pressure into the concrete. In front of each waterbed there are aluminium strip and stainless steel anchors. At the end of each row there are waterbeds anchored with strips and anchors of stainless steel. The beds are then individually filled with water to ensure maximum cow comfort. There are about 53 litres of water in one waterbed. During the use of waterbeds do not need to change or add water. The fill of tube is sufficiently well sealed with three-piece stainless steel cap (ACT, 2012).

Double chamber cow waterbeds are made by American company Advanced Comfort Technology, Inc. -ACT. Waterbeds are used as possible solution of bedding in more than 20 countries. It is provide unchanging, stable and dry

Vol. XVII (2013), no.2 
surface every time the animals lie down. Unlike other types of bedding do not occur to her unwanted getting to sides of beds and give rise to pressure sores or abrasions limbs of animals (Throndsen, 2013).

The aim of the study was to judge the improvement of animals' welfare in the introduction of new technology of cattle housing in the form double chamber cow waterbeds and their influence on health condition of dairy cows and heifers. They were measured: effects on milk production of dairy cows, the level of somatic cells in milk of dairy cows, the incidence of mastitis in dairy cows and the proportion of animals that were culled from breeding due to leg injuries.

The premise is that well chosen solution can help overcome problems those occur and at the same time avoid of further risks. Dairy cows provide sufficient comfort and care, improved health. Reduce the costs of treating diseased or injured animals and increase milk production to milk producers.

\section{MATERIALS AND METHODS}

Introduction of new housing technology into the service was held in October 15. 2012 after reconstruction of stable for cows and heifers of Holstein breed with free boxing stabling in the village Lom of Agricultural Company Slapy a.s.

The building of reconstructed stable is composed of steel supporting structure with a gabled roof. Peripheral walls are designed with built peripheral covering networks, which can be downloaded as needed. Above the feed corridor was made a new roof-light that brings in the stable dispersed daylight. Old metal fencing was exchanged with new metal fencing. There was installed into the boxes for dairy cows and heifers new double chamber cow waterbeds that do not require another consumption of material for extra beds.

Rubber mattresses were unsatisfactory with their properties for dairy cows and heifers. Animals suffered from inflammatory diseases of the uddermastitis and diseases of the limbs, swollen hocks.

These reasons were during the reconstruction exchanged. The rubber mattresses were exchanged for new double chamber waterbeds of American producer Advanced Comfort Technology, Inc. -ACT, the distributor is BUC Holland International BV.

The data information was taken from the farm records of Agricultural Company Slapy a.s. The data of number of dairy cows culled from the herd due to culling and the limb injuries and data of course of mastitis in the herd

Vol. XVII (2013), no.2 
of dairy cows, milk production and values of the somatic cells in milk was processed and evaluated in graphs using Microsoft Excel.

\section{RESULTS AND DISCUSSIONS}

In Figure 1 is shown curve of numbers of dairy cows which were discarded from breeding due the culling and the curve expressing what part of culling dairy cows formed the discard due injury to the limbs. Change of stabling technology was in October 15. 2012. This date is designate in Figure 1 with a cross.

The values for the period from October 2012 to June 2013 show a significant reduction of number of dairy cows. Dairy cows were removed from the breeding grounds due disease of the limbs. Compared to the period from May to October 2012 when cows and heifers were stabled on rubber mattresses that did not meet enough the breeding requirements. The old stabling was too hard, without an extra bed that caused poorer quality of lying. Dairy cows suffered from significant pressure sores of the hocks. The new doublechamber cow waterbeds without extra beds provided cows and heifers greater comfort that also showed a lower incidence of pressure sores of the hocks. Comfort of dairy cows and heifers recorded in Figure 2 and Figure 3.

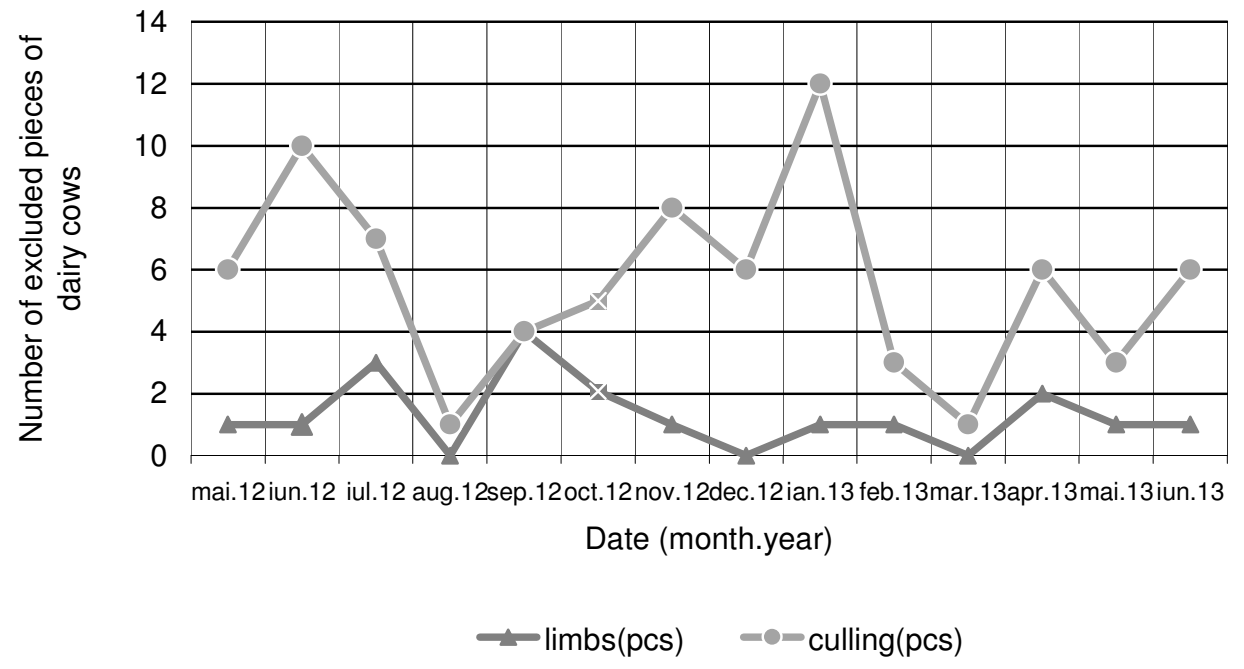

Figure 1. Dairy cows excluded from breeding of the herd

Vol. XVII (2013), no.2 


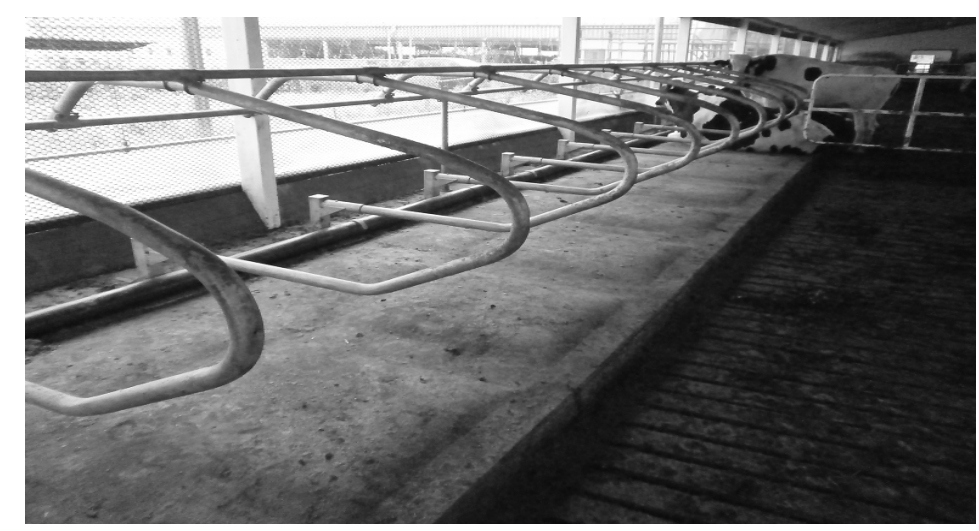

Figure 2. Double chamber cows waterbeds

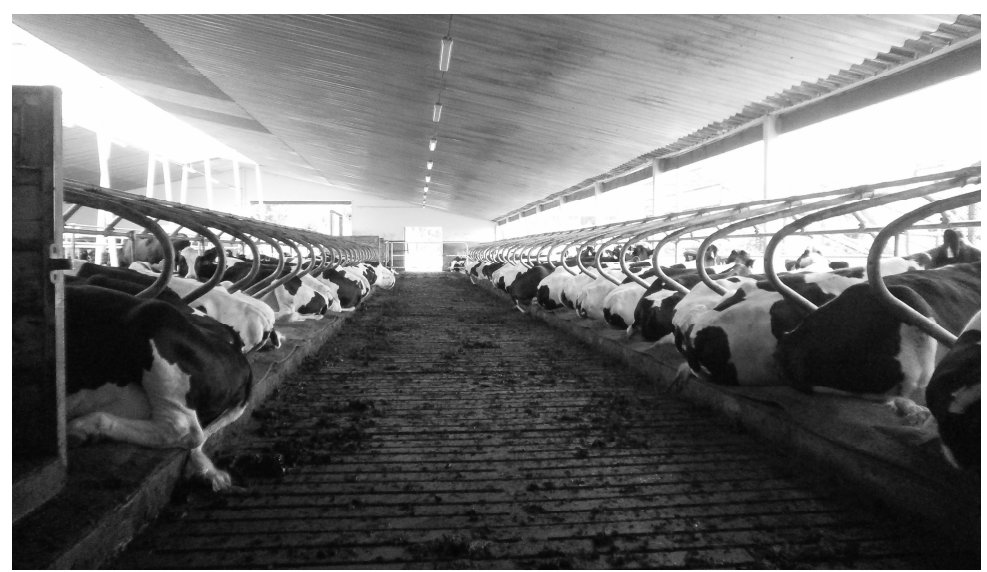

Figure 3. Double chamber cows waterbeds in using

Double-chamber cow waterbeds reduce the incidence of diseases of the limbs, especially the incidence of pressure sores of the hocks (Throndsen, 2013). Better health of limbs after using the double- chamber cow waterbeds were confirmed in cows (Fulwider et al., 2007a). At the same time the part of culling cows were according the study lower in case of using the doublechamber cow waterbeds.

The count of somatic cells in the milk of dairy cows recorded Figure 4 for the period from July 2012 to June 2013. The milk samples were taken away always three times each month. Highlighted point cross indicates a change of stabling technology in the month of October 2012.

The average values of the somatic cells were in the milk of dairy cows 209 thousands/ml for the period from July to October 2012. The average values of somatic cells in milk were 211 thousands $/ \mathrm{ml}$ for the period from October 2012 to June 2013. In comparing these periods, before and after using

Vol. XVII (2013), no.2 
double- chamber cow waterbeds, show no significant differences in the count of somatic cells of taken samples. The effect of waterbeds was not enough evidential.

The effect of rubber mattresses and double- chamber cow waterbeds on the count of somatic cells in milk has not been demonstrated. In the study was compared the stabling of cows on rubber mattresses, sand, and waterbeds. Values of experiment came out very similarly.

Dairy cows stabled on rubber mattresses had 241.4 thousands/ml somatic cells in milk. In the case of sand was the value 235.2 thousands $/ \mathrm{ml}$ of somatic cells in milk. Waterbeds had the lowest value of 232.0 thousands $/ \mathrm{ml}$ somatic cells in milk (Fulwider et al., 2007b).

The stabling technology is one of the environmental factors that can influence the formation and development of mastitis. Figure 5 shows the frequency of occurrence of mastitis in dairy cows during the period from July 2012 to June 2013. The beginning of using double- chamber cow waterbeds is highlighted in the graph with the cross. The character of curve of total number mastitis in the herd recorded gradual loss of dairy cows that became ill with mastitis, despite the slightly increase of incidence of mastitis in December 2012. The total decline is valid for lighter even more severe disease.

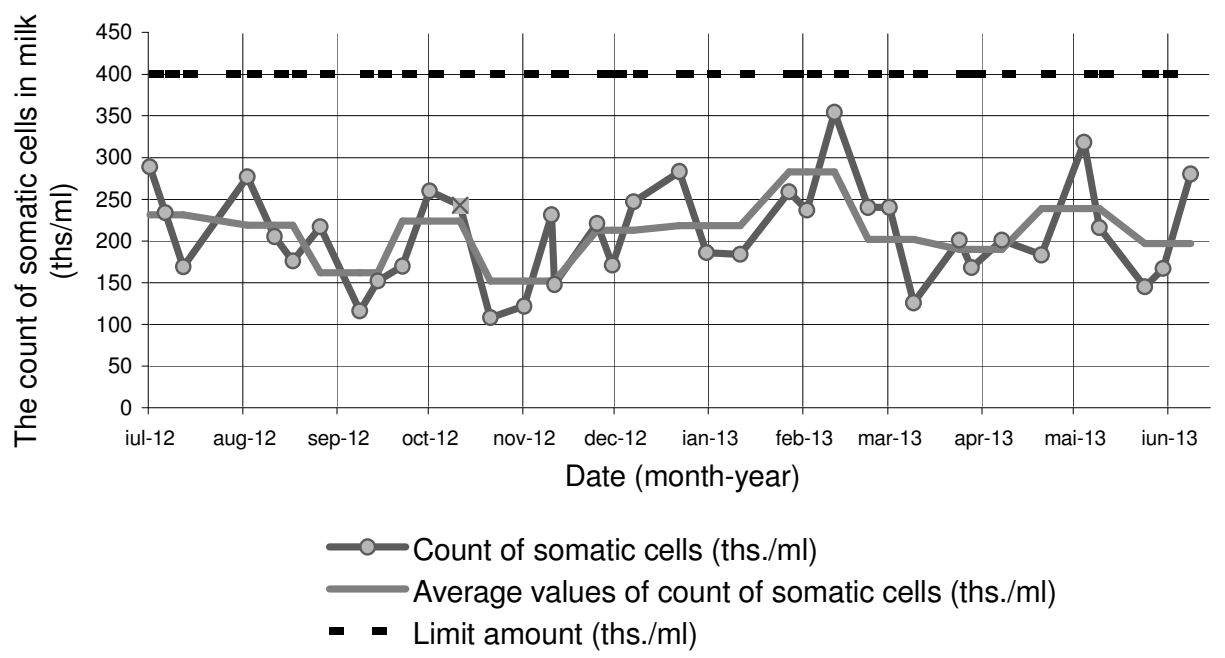

Figure 4. The amount of somatic cells in milk

Double- chamber cow waterbeds enable the milk or urine to flow off from the cushions because waterbeds have rounded shape of the cushions. This

Vol. XVII (2013), no.2 
technology keeps the animals clean and dramatically reducing the risk of infection. More of dairy cows are cleaner less suffered from mastitis (Ward et al., 2002).

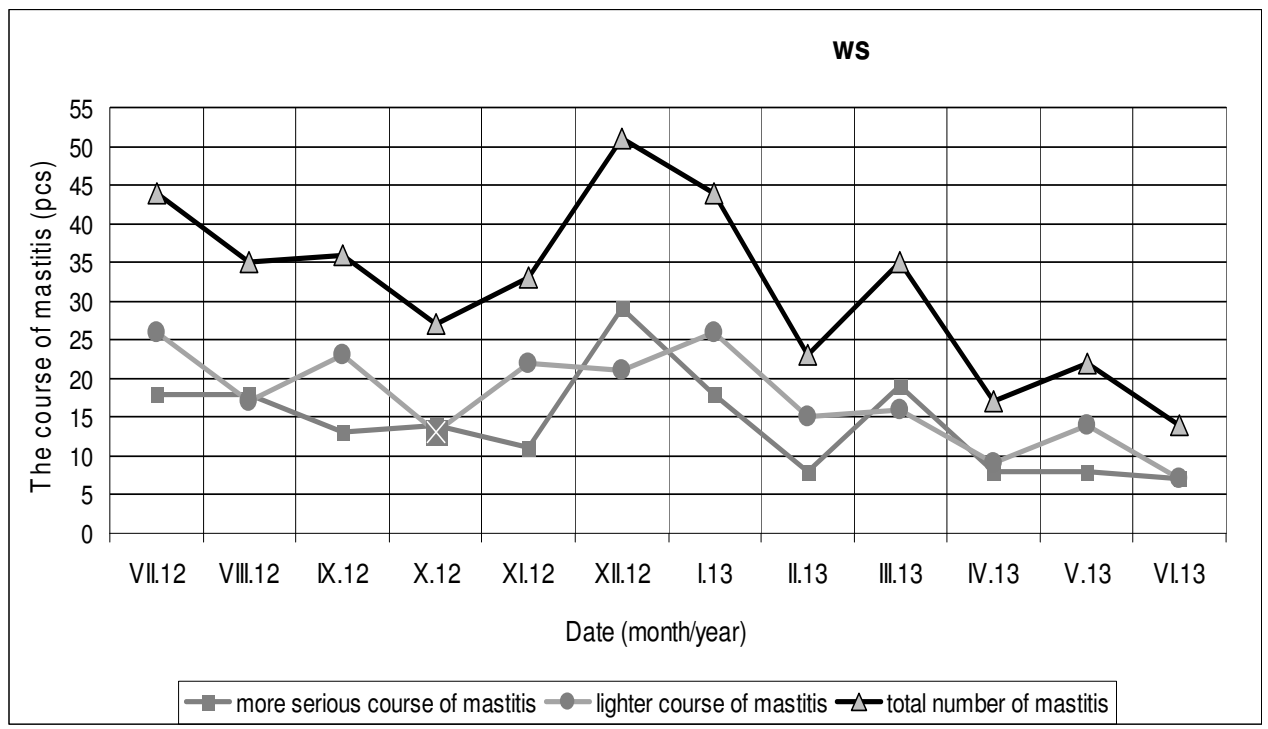

Figure 5. The course of mastitis in dairy cows

Figure 6 records the value of milk production of dairy cows with regard to the number of animals in the herd and average milk production per dairy cow in litres per day, for the period from January 2012 to June 2013.

Milk production gradually increased since October 2012. The average monthly milk production was 76 557litres of milk for the period from January to October 2012. The average monthly milk production increased to 97 557litres in the period from October 2012 to June 2013. Milk production has continued to rise in July 2013. Despite the fact that milk production declines over the summer months (Brouček et al., 2009). Increased production was reflected in the average production per cow. Cows' average values of production were increased by an average of 3litres per day.

Milk production should increase after the introduction of waterbeds about 15\% (Throndsen, 2013). From the measured values so far come out that milk production in the Agricultural Company Slapy a.s. increased by $17 \%$.

Vol. XVII (2013), no.2 


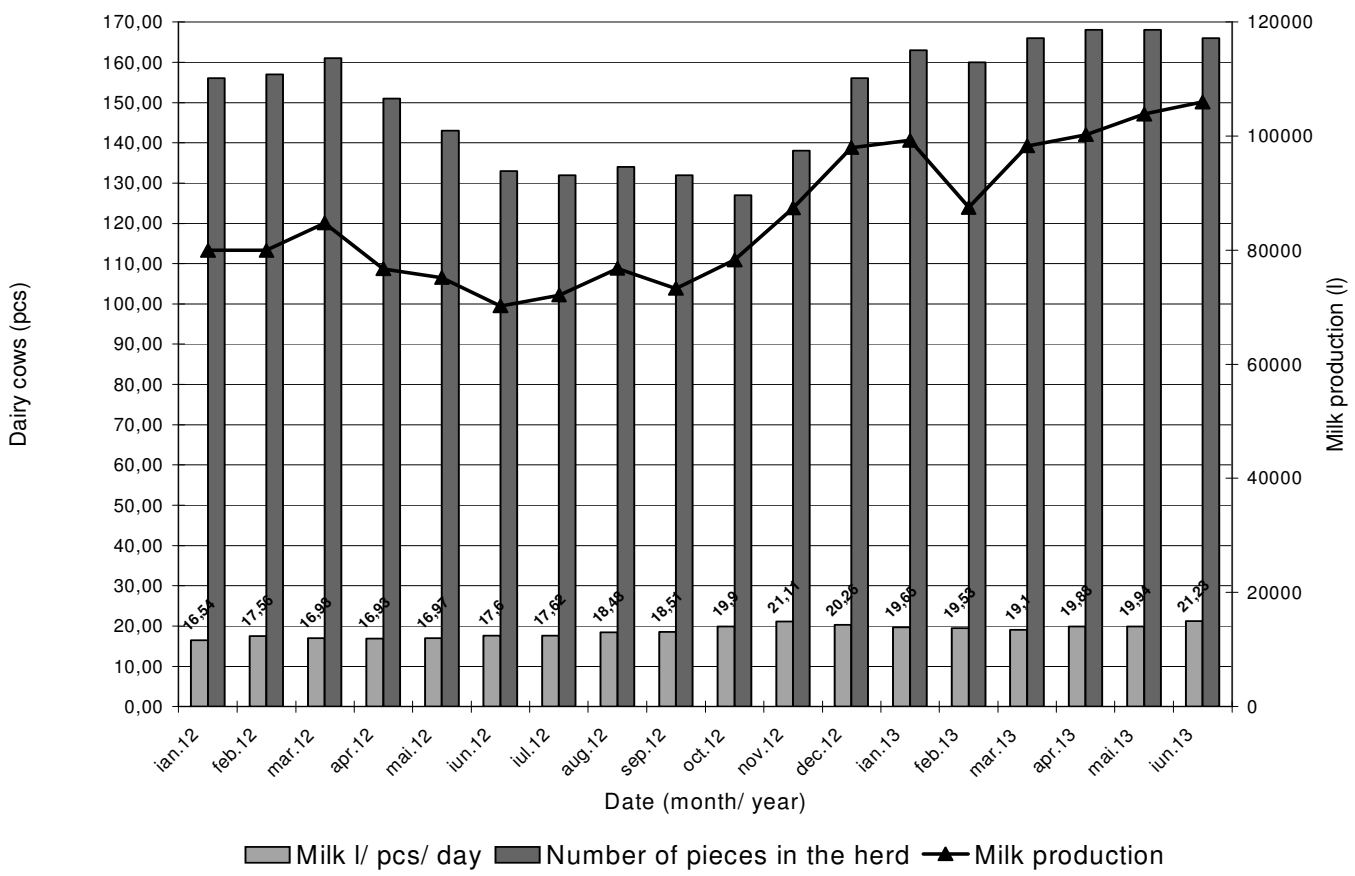

Figure 6. Milk production of dairy cows

\section{CONCLUSIONS}

The introduction of new stabling technology double-chamber cow waterbeds reduced numbers of dairy cows and heifers with injuries of the limbs in the stable. Effect on counts of somatic cell was not enough proven. Their values were rather constant. In the breed of dairy cows and heifers during the period was recorded a lower incidence of inflammatory diseases of the udder of dairy cows- mastitis. The reason is a cleaner environment with less risk of contamination of teat of dairy cows with dirt. Milk production increased constantly during the period. The positive effect of double- chamber cow waterbeds was found in individual milk production of dairy cows per a day. The animals were calm and cleaner. It increased the number of dairy cows and heifers lying in the boxes by the double chamber cow waterbeds.

\section{ACKNOWLEDGEMENTS}

This article was written during realization of the project NAZV QJ1210144 and GAJU 020/2013/Z

Vol. XVII (2013), no.2 


\section{REFERENCES}

1. Advanced Comfort Technology, Inc. (2012). DCC Waterbeds. Dual Chamber Cow Waterbeds. Retrieved Jun 25, 2013, from http://www.tseio.com/ CDs/PDPWYITAXD/files/AdvaIYWR/2012\%20DCC\%20Waterbeds\%2 0Info\%20Guide.pdf

2. Brouček, J., Novák, P., Vokřálová, J., Šoch, M., Kišac, P. \& Uhrinčat', M. (2009). Effect of high temperature on milk production of cows from free-stall housing with natural ventilation. Slovak Journal Animal Science. 42(4), 167-173.

3. Cziszter, L.T., Sossidou, E.N., Szücs, E., Acatincăi, S., Erina, S., Baul, S., Tripon, I. \& Gavojdan, D. (2011). Do Romanian Farmers and Consumers Have Different Views on Farm Animal Welfare Issues? Scientific Papers: Animal Science and Biotechnologies 44(2), 285-291.

4. Fulwider, W.K., Grandin, T., Garrick, D.J., Engle, T.E., Lamm, W.D., Dalsted, N.L. \& Rollin, B.E. (2007a). Influence of Free-Stall Base on Tarsal Joint Lesions\& Hygiene in Dairy Cows. Journal of Dairy Science. 90(7), 3559-3566. DOI: 10.3168/jds.2006-793

5. Fulwider, W.K., Grandin, T., Garrick, D.J., Engle, T.E., Lamm, W.D., Dalsted, N.L. \& Rollin, B.E. (2007b). Effect of Stall Base Type on Herd Health, Costs, and Producer Satisfaction. In: Sixth International Dairy Housing Conference Proceeding. 16-18 June 2008 (pp. 1-7). Minneapolis, Minnesota, USA: American Society of Agricultural and Biological Engineers.

6. Mowbray, L., Vittie, T. \& Weary, D. M. (2003). Hock lesions and freestall design: Effects of stall surface. In Proceediogns $5^{\text {th }}$ International Dairy Housing Conference. 9-31 January 2003 (pp. 288-295). Fort Worth, Texas, USA: American Society of Agricultural and Biological Engineers.

7. Vokey, F. J., Guard, C. L., Erb, H. N. \& Galton, D. M. (2001). Effects of alley and stall surfaces on indices of claw and leg health in dairy cattle housed in a free-stall barn. Journal of Dairy Science. 84(12), 2686-2699. DOI: 10.3168/jds.S0022-0302(01)74723-6.

8. Ward, W. R., Hughes, J. W., Faull, W. B., Cripps, P. J., Sutherland, J. P. $\&$ Sutherst, J. E. (2002). Observational study of temperature, moisture, $\mathrm{pH}$ and bacteria in straw bedding, and faecal consistency, cleanliness and mastitis in cows in four dairy herds. Veterinary Record 151(7), 199-206. DOI: $10.1136 / v r .151 .7 .199$

Vol. XVII (2013), no.2 
9. Weary, D.M. \&Tucker, C. (2003). The science of cow comfort. Proceedings of the Joint Meeting of the Ontario Agri Business Association and the Ontario Association of Bovine Practitioners, April 2003 (pp. 23-49). Guelph, Ontario.

Vol. XVII (2013), no.2 